\title{
The Same Free Soul Under Different Sky-A Comparative Study About Qiu Jin and Mary Wollstonecraft From Feminism Perspective
}

\author{
SHI Shao-hua, ZHAO Guo-dong \\ Inner Mongolia University of Finance and Economics, Huhhot, China
}

\begin{abstract}
Qiu Jin was a legendary female figure in Chinese modern history; Mary Wollstonecraft has always been regarded as the founder of Western feminism movement and the earliest feminist as a British writer and philosopher. These two heroines not only established their own feminism thoughts in their own limited boundary under limited condition, but most of their feminism ideas are astonishingly similar. Besides, these two heroines never surrender to a miserable life, painful sufferings, even abuse and betrayals from their beloved ones. This paper analyzes the different aspects of these two heroines, who are from two different countries and live in different eras, and uncovers the author's own ideas towards female's freedom.
\end{abstract}

Keywords: Qiu Jin, Mary Wollstonecraft, feminism, comparative study

\section{Introduction}

\section{Morning Star-Road of Feminism}

Since the year of 475 BC, when ancient China's Warring States period began, the long and dark feudal society spread all over China. This was the beginning in China of men oppressing women, the patriarchy era. From then on, thousands and thousands of females lost their sacred status which was set up firmly in the previous matriarchal society, in other words, for well over a thousand years, the collapse of the matriarchal society led to the fall of female's social and financial status.

As is said in Woman Precepts (around 90AD) written by Ban Zhao, a traditional and virtuous lady should obey the golden rule of "the three obedience and the four virtues" which tells that the standard woman image is saying yes to everything a man said and never ever expresses her ideas. Saying something loudly, rationally and reading some books are considered to be rude and ignorant. In a word, woman was tightly suppressed under patriarchy and in feudal society. Besides, the policy of isolation toward the outside world made this situation even worse. New ideas and new thoughts could not penetrate into China.

So under the ruling of feudal society, patriarchy created so many ways of torturing females. Since the South Tang Dynasty, the emperor Li Yu gave a nation-wide order for females called foot-binding which aimed to make

SHI Shao-hua, lecturer, Master in Art, School of Foreign Languages, Inner Mongolia University of Finance and Economics.

ZHAO Guo-dong, associate professor, Master in Art, School of Foreign Languages, Inner Mongolia University of Finance and Economics. 
woman's feet never grow up into normal shapes and sizes but crushed them into three-inch long, lotus-shaped twisted feet. Foot-binding actually is to make woman feet's metatarsal bones dislocated or even fractured through completely physical power, people would use a special stripe of cloth to twine a girl's feet one layer after another, and this physical suffering began at the age of 4 or 5. Everyday, a girl would wear this set of torture tools, suffering pains beyond description and because of this, women could not walk quickly or go out of home, some women even become disabled or even died. There was a local saying that "feet binding, tank teardrops". This extremely evil practice began to torture women’s body and mind; women became more physical and mental inferior to men.

Things were similar in 18th century Britain. Women were treated as inferiors. A lady's marriage prospects were closely connected with her dowry. It can be seen in Jane Austin's Pride and Prejudice (2006) that ladies were desperate to marry a rich man because a lady's future depended on a man. Elizabeth's close friend, Charlotte, a rational and beautiful lady, married the snobbish and boorish Mr. Collins who had just proposed to Elizabeth and got ruthlessly rejected. The only reason Charlotte married Mr. Collins was that she did not want to be a burden to her family anymore. And since her family could not prepare her an abundant dowry, so she had no choice but to marry Mr. Collins. Apparently Charlotte just could not let go the last chance of marrying someone who could support her.

In a word, in Britain females were set as inferior to males from birth. Females had always been living in a world ruled by males and there was no freedom or legal rights for females in the patriarchy society of the time.

\section{Guiding Stars}

Often when the feminism movements at home and abroad are mentioned, two figures come to mind because they are the earliest pioneers, for their extraordinary, profound, and outstanding feminism thoughts; they are Qiu Jin from late Qing Dynasty and Mary Wollstonecraft from Great Britain.

Qiu Jin was born at a tragedy time of the late Qing Dynasty, when the once splendid China had been torn into pieces by the Eight-Power Allied Forces with cannon and opium on their hands. They obtained endless benefits through unfair trade and unfair contracts. But on the bright side, these foreign businessmen also introduced advanced ideas from the West; particularly the preachers who established several schools for females, which were the earliest in China. "Endowed Human Right”, "equality for every human beings”, and ideas of this kind now came into this abundant and weak China, giving inspiration to those who were eager for China to be strong and long for own freedom. Qiu Jin was the earliest and the unforgettable one.

Qiu Jin (1875-1907) has always been seen as the first female leader who advocated and participated in China's earliest woman movement, the first one to accept and spread the idea of "equality of both sexes", and the fundamental founder of China's feminism movement. Sun Zhongshan, the President of National Republic of China, designated Qiu Jin as the honorary of “Qiu Association”; Mr. Lu Xun’s great work Medicine (1919) was created based on Qiu Jin; President Zhou En'lai also mentioned and praised Qiu Jin for many times. There is no doubt that with so many honors.

Qiu Jin called women to wake up to pursue their own happiness and to stand up to fight for their own benefit. She enthusiastically gave out speeches on teaching females to be independent both home and abroad, not only fighting against the patriarchy's powers, but also participating in various liberation groups or associations. In a 
word, Qiu Jin was a great female revolutionist.

The other great heroine, Mary Wollstonecraft (1759-1797), who has been seen as a great British writer, philosopher, and founder of Western feminism, contributed to woman's liberation in Britain. Mary left the readers beings with her masterpiece, Vindication of the Rights of Women (1792), which has been seen as the first internationally influential works for woman's movement's theoretical system and the base of feminism.

Mary Wollstonecraft's ideas came into being by the late of 18th century, which was called the "Revolutionary Era". The ideas of "reason and sensibility" advocated by the enlightenment movement and the onslaught of French Revolutionary changed the arbitrary patriarchy society. Ideologists during the enlightenment movement fiercely fustigated the inequality and illiberality and fought against the hierarchy and personal bondage of feudal society. Rousseau's "All human beings are born free and equal in dignity and rights" and ideas of "freedom, equality and fraternity" educated all the human beings, most importantly, people also began to realize the situation of women, and many women were woken up by the democratic ideas.

The enlightenment movement was a glorious period when talking about respect for individual and for subject consciousness became more common. Particularly with the Galileo's geocentricism, Newton's universal gravitation, and other scientific discoveries, both educated and common people realized the universal truth instead of believing only in religion or immortal powers. In 1789, with the coming of French Revolutionary, "all human beings are endowed with God-given rights", "being free and equal”, and ideas of this kind shook the scattered and battered feudal society which soon began to collapse. Many women began to realize that a woman's destiny was not set from the moment of birth.

Among these, Mary Wollstonecraft was among the bravest, because in order to experience the magnificent French Revolutionary, she went to Paris alone. The stay in Paris was terrifying, and she almost died there. Many friends of Mary's were sent to the guillotine (Montero, 2005). During this vivid and afflicting trip to Paris, Mary clearly saw that women from all fields and ranks joined in the revolution actively and bravely even paid with their lives. But men refused to meet their promises, instead, continued to take women as the lower rank to men, they still claimed that women belonged to the kitchen and the yard. This political circumstance provided Mary Wollstonecraft with a unique perspective of thinking.

From the above paragraphs, it can be concluded that although Qiu Jin and Mary Wollstonecraft were from different eras and countries, they still have several things in common. The first and the most obvious one is their rebellion consciousness fighting against patriarchy to purse their own freedom and being themselves. Qiu Jin went to Japan to pursue truth of saving her country and people while Mary went to Paris to see how female participated in the liberation movement; Qiu Jin unbound her "three inch golden lotus feet" to encourage other women to wake up while Mary Wollstonecraft left her indifferent noble family to live on her own; and the most important one, both Qiu Jin and Mary Wollstonecraft accepted Rousseau's ideas of being equal and so on, under these democratic and liberal teachings, the earliest feminism pioneers were born.

The second one is that the two great figures both were living in a changing society where advanced ideas and old ideas conflicted. The 18th century was a magical era when the long-sleeping independent consciousness began to awaken and the women with sharp foresight began to observe the patriarchy society they were trapped in and begin to find their roads to being free and independent. Qiu Jin sensed this turbulent stream of pursuing liberation and freedom would win the final victory so she never surrendered to destiny or the corrupt Qing 
Government while Mary Wollstonecraft noticed that if females did not liberate themselves, no one was going to rescue them. These two feminism pioneers encouraged women to shake off the fetters of men and family's, to break away from the feudal regulations' trammel, to cast off the stigma and wrong labels imposed by males. The truth that a woman was born as equal and as smart as man made it reasonable and normal for a lady to have rights of education and making decisions on her own.

The third one in common is that both the two pioneers had persistent characters. Though many difficulties stood in their way of pursing freedom, they never gave up but went forward; they never bowed to destiny nor the outside powers but chose to be true to their own inner desires; though fate intervened at times, they never surrendered but kept following their dreams.

With these three merits, nothing would stop them. These two figures gave people the understanding that the true and authentic equality means equality under the law in daily life, both suitable for males and females, and both in philosophical and social aspect for men and women

\section{Great Women of the Era}

\section{Different Childhood Dreams}

Since the Opium Wars, the eight powers or the "the red hair" opened China's gates by cannons and violence. From that moment on, the Chinese people had to suffer pains and suppression from both the feudal rulers and also the overseas invaders. Especially after the first Sino Japanese war of 1894-1895, the foreign invaders began to scramble for China, this big juicy cake. All the invaders wanted to subjugate China for her abundant natural resources and infinite treasures. Facing this dying and critical moment, every conscious Chinese needed to take up what they had by hand and fight for the country's independence and existence.

Qiu Jin was born in a royal, traditional, and incorruptible family who in previous generations began to work for the Qing Dynasty. Qiu Jin accompanied her grandfather and father who transferred from Fu Jian province to Tai Wan and finally Hu Nan. This experience at a young age gave her a broad experience, multiple perspectives of thinking, and a strong sense of patriotism.

Qiu Jin's hometown was Shao Xing which is rich for countless patriotic personages, such as Da Yu who dredged the Yellow River for 13 years but never come into his own home even walked by the door gate, peasant Yao Zhangzi who fought back the Japanese pirates, and Emperor Gou Jian of State Wu who slept on the brushwood and tasted the gall just in order to take his own state back from his former enemies. Besides those ones, the famous female poet Li Qingzhao, patriotic poet Lu You and Du Fu were all born in Shao Xing. This hometown's strong patriotic atmosphere granted Qiu Jin with a strong sense of protecting her country and these people's brave stories produced indelible effects on the teenaged Qiu Jin's mind which lay a foundation of patriotism in her heart.

This was quite different from Mary Wollstonecraft whose feminism ideas came from her own miserable and unhappy experience. Mary Wollstonecraft was born in 1759 from a fallen middle-class family whose father kept committing family violence and drinking excessively. In order not to give her father any chance of hitting her mother, Mary had to sleep outside her mother's door during her teenage times. This unstable and poor drifting experience plant a seed of hatred for men at a young age. Later, her sister's marriage replayed this tragedy again. On seeing this, Mary rescued her sister by helping her escape from her husband's house. These miserable and 
pathetic issues kept taking place until the age of 16. An event changed Mary Wollstonecraft completely. Mary seldom made friends with others, but Fannie Blood (1774) was an exception. Fannie was an educated woman whose behaviors and sayings produced a positive effect on Mary.

So Mary Wollstonecraft's feminism ideas originally came from her own dreary and lonely childhood memories and personal experience which produced limitations on thinking. Her fundamental idea is about how to become independent through proper education and if possible, not get connected with a man by marriage. Marriage she saw as a horrible tomb for women due to her father's image.

Qiu Jin was very different because she treated woman's problem with a radical and violent attitude. She worshiped Bismarck's tough approach very much which settled conflicts through ruthless means (YU, 2007). During her studying in Japan, Qiu Jin organized a donation activity just in order to help two concubines to be ransomed free.

\section{Significant Education}

Qiu Jin grew up in a rich family which offered her a good education as that she could read and write what she wanted to. And second, Qiu Jin's mother was traditional and kind and her father was generous and democratic; they gave Qiu Jin the best elementary education by telling her many patriotic stories and always supported her, even when Qiu Jin decided to dress like a man and participated in revolutionary activities. Compared with Mary, who just went to the day school for a short while, Qiu Jin's education circumstance was much better and this granted Qiu Jin possibilities of cultivating rational thinking and offered her a broader understanding.

In Mary's time and society, it was rare for females to have chances of education. Though there were already several schools for middle-class ladies, the only purpose of this kind of school was to train ladies to be elegant and good-mannered so they could marry a better man. Mary was very dissatisfied with this limited education chance for girls so she brought the claim that society and government should offer more chances for girls to read and write, not just for future marriage but on the sake of developing a lady's own way of thinking and expressing which was based upon her own story and inner desires.

But Qiu Jin's ideas of asking government to offer girls more chances of having education came from the thoughts that only the ability to know about history can give ability to protect one's country. Even with this difference, Qiu Jin and Mary Wollstonecraft share one thing in common, to give girls more chances of education because only education can develop a girl's ability to support herself, to be financially independent, to be free from man's supervision, control, and suppression.

\section{Pathetic Marriage but No Pathetic Women}

Even though Qiu Jin's parents gave her free chances of accepting education, such as read and write, still they were feudal inside. Qiu Jin suffered from foot-binding and seldom went outside the home.

Having seen too much invaders' bullying common people and Qing Dynasty's flabby policies, Qiu Jin decided to learn martial arts, horse-riding, fencing, and archery, even when her feet were too small to tolerant these fierce actions. After practicing, Qiu Jin's feet were always bleeding and swelling. This experience cast an iron-strong personality of Qiu Jin.

At the age of 22, under her parents and matchmaker's arrangement, Qiu Jin reluctantly married Wang Tingjun, who possessed a woman face, slim body figure, and a weak personality. The most important part is that 
Wang Tingjun's father had been a poor and ignorant farmer; but became rich overnight since he became Zeng Guofan's accountant because he was one of his distant relatives (YU, 2007).

After marriage, Qiu Jin became more and more distressed. Qiu Jin longed for a husband who had shared interests, knowledge, personality, and character, but Wang Tingjun certainly was not the right man. Born in a family which highlight money more than inner heart surely granted Wang Tingjun a personality which can be described as stingy, snobbish, indifferent, disloyal, bragging, selfish, whoring, and nasty. Qiu Jin once said that she acted as the husband and Wang Tingjun acted as the wife. Later, after Qiu Jin’s father's death, Family Wang began to abuse Qiu Jin, even once Wang Tingjun hit Qiu Jin. Qiu Jin could not put up with this cold-blooded, snobbish, and corrupted husband anymore, she went to Japan to pursue truth of saving herself, saving Chinese women and China.

But married a rich man who can support wife and family is luckier than being cheated. Mary Wollstonecraft, who advocated never getting married was cheated and betrayed several times. She acclaimed to the public that she was crazy in love with a married man who accepted her affection but abandoned her two years later. This broke Mary's heart. Later, on a trip to America, she met a loafer who once again cheated her and this time, Mary Wollstonecraft gave birth to a baby girl. When the dawdler wanted to discard her and her daughter, Mary Wollstonecraft attempted suicide twice. These grieved love affairs made Mary Wollstonecraft begin to reckon on a woman's outlet rationally and calmly.

So it is easy to say that no matter whether you are educated or what kind of family are you from, marriage is always the same. Marriage is a cage where you can never fly out or live on your own mind. It is pathetic and hopeless if a woman wants to take her husband as the main resource of happiness.

Qiu Jin was a persistent lady who never surrendered to difficulties or unfair destiny, which made her will to revolt even stronger and more fiercely. Based on her own experience, she brought out the idea of "revolution should begin from one's own house", which is called "family revolution". This is the starting line of social liberation. On how to realize family revolution, Qiu Jin put forwards her primary feminism ideas of "self-reliance, learn skills, sociable”.

Self-reliance means that woman should cultivate the belief that woman can support herself through learning some skills that can make woman become financially independent. Not depending on man for money, woman can have the basic condition of pursuing her own dream. Woman should choose to take up some skills according to their own qualification, interest, and future plan. And if possible, education is the first priority. And the third one, sociable means woman should unite to set up some organizations to achieve freedom and happiness together. Mr. Guo Moruo once commented Qiu Jin’s feminism ideas like this, “Qiu Jin not only set up an example for Chinese women's liberation movement, but for the national liberation movement as well” (as cited in ZHOU, 2009, p. 113).

While with the painful lessons, Mary Wollstonecraft began to observe how the patriarchy society treated women. Why could not the women live as wonderfully and freely as men did? Why were women always the inferior and disadvantaged ones? Mary Wollstonecraft accepted Rousseau's ideas critically. She supported his "All human beings are born free and equal in dignity and rights" and ideas of "freedom, equality and fraternity", but on the other hand, she could not agree with his ideas that women belong to the second sex and should obey men unconditionally. Based on her experience, observation, and reckonings, Mary Wollstonecraft stressed that 
rationality and merit are the same, if rationality is power granted by God, then, this tie connected God and human beings, thus should be the same for both sexes.

She explained that woman's inferiority can be taken as physical weakness, ignorant, narrow-minded, superficial, which could be traced back to their limited and insufficient elementary education. In other words, woman's inferiority came into being after birth.

Being encouraged by the enlightenment movement and rationalism, Mary Wollstonecraft reconsidered all the advanced theory and ideas; she established her own unique feminism ideas with a critical thinking and bold attitude.

Qiu Jin's feminism ideas came out of life, family's edify, a miserable marriage life, enlightening ideas obtained from studying in Japan and intimate friends during the revolution activities. All those experiences helped Qiu Jin cultivate unique revolutionary ideas. Secondly, Qiu Jin always contended to achieve liberation through violent armed rebellion and revolution. While studying in Japan, Qiu Jin found it very necessary to spread revolutionary, free, and liberation ideas through making good and persuasive speeches. So she practiced oral ability a lot by joining in the "speech association" and initiatively to improve her oral skills. Qiu Jin once said, "it is a must to civilize common people and touch them by addressing” (SHEN, 1988, p. 24). Besides this, Qiu Jin established Colloquial Chinese Newspaper which aimed at women whose culture was not so high.

Coincidentally, in 1784 Mary Wollstonecraft established a school for ladies. Mary Wollstonecraft criticized the 19th century's popular custom that women were served as the decoration of their living rooms; women were destined to take orders from their masters, husbands. Wollstonecraft pointed out that the social education for woman made the noble ones become flighty and the poor ones become lost in vanity and indulge in creature comforts. So on education for women, Wollstonecraft put forward several ideas. The first one is that it is very necessary for women to accept proper education on rationality. She pointed that the perfect education aimed to build up body strength, cultivate spirit and a carefully-planned rationality practice, and then to grant women independent personality and habits. Wollstonecraft did not deny woman's born characteristics, such as emotional, kindness, and passion.

Second, Mary made the importance of family education and school education clearly. She suggested that the country should establish day schools to realize national education (LIU, 2008). This idea came up after Mary compared the advantages and disadvantages of private schools. She always held the idea that public ethics came after personal ethics. The children, especially the girls should go to school together to develop the most priceless affection-friendship and cultivate each other's mental power and independent character.

Third, it is rare and commendable for Wollstonecraft (2006) to bring forward an idea of mother's education. A mother always succumbed to the father in a family's relationship.

Mary Wollstonecraft showed her unique and advanced feminism ideas through her actions, such as establishing schools and education focused on rationality for females, but this also made her isolated from other females. Mary's occupation and friend group made her become lonelier. Her ideas were sharp and unique; the males took her as talented and radical, while the female friends took her as a bit weird.

In contrast, Qiu Jin's behavior was much more popular and got most people's support and understanding. While she was studying in Japan, many classmates and friends strongly supported her by joining in the revolution organizations and she was once chosen the team leader of Death squads when they heard that the Qing 
Government forbade patriotism activities and restrained their freedom. The students abroad followed Qiu Jin devotedly and passionately.

Her newspaper Chinese Woman gave the massive number of Chinese women who were in darkness and under patriarchy's control for thousands of years a deep and vivid lesson on liberation and pursuit for happiness. This was the first time they were encouraged to think about themselves and think about their social status or a future of being herself without man's, or husband's, or even son's guiding, management, and supervision.

Besides education, Qiu Jin firmly believed in an armed struggle to overthrow the Qing Government and expel foreign invaders. Qiu Jin had long realized that only the social liberation movement can liberate women completely. She practiced martial arts at a young age, and after coming back from Japan, she and her fellows organized an uprising in 1906 in Hu Nan, which was her hometown. Qiu Jin was also an exert in explosives making. She was the chairman of Da Tong school which trained military talents and purchased and taught students how to use weapons, such as guns, swords, and knifes. Many students described Qiu Jin as wearing in man's uniform, holding a browning pistol in chest and an enemy knife at the waist, commanding students while riding a horse. Students and kids called her Uncle Qiu instead of Aunt Qiu.

To conclude, Qiu Jin yearned to set up a whole-new society where both males and females respect each other through armed struggles, while Mary Wollstonecraft longed for a new relationship between female and male which can be called equal and cooperative. This was a new relationship which was integrated with mutual caring and mutual respect.

All in all, in several aspects, Qiu Jin was more thorough, radical, and rational than Mary Wollstonecraft. Qiu Jin always believed in violent means to overturn the old and set up a new one. If the Qing government was too corrupted to be placed trust and hope on, then it should be overturned. While, Mary Wollstonecraft showed a kind of compliance to patriarchy, which can be inferred from her propositions, such as how to be a qualified and good mother and housewife, both two sexes belong to their exclusive fields, and so on. Mary Wollstonecraft strengthened on regulation rather than setting up one's own domain.

\section{Lovable Friends}

With the invasion of the big powers from across the world, Beijing was turned into a semi-feudal and semi-colonial city for about 100 years which made Beijing a place of fusion, new ideas, and sparks. The earliest and the most radical Chinese Revolutionary League were all born here, such as Tung Meng Hui. These leagues established various newspapers to awaken the common people, gave endless touching speeches to teach common people the truth and principles and even organized many brave uprisings to achieve their dreams of having a strong, independent, and rich China.

Qiu Jin accompanied her husband to pay for official positions three times. Each time Qiu Jin went to Beijing, she became more and more rebellious at her husband's behavior and the late Qing Government's corruption and incompetence; on the other hand, her motivated friends, such as Wu Yingzhi couple, doctor Takayuki from the imperial university of Peking, influenced her greatly. The trips to Peking became more enlightening and stimulating than miserable.

Besides these two earliest guides who enlightened Qiu Jin's self-consciousness awaking, Qiu Jin was also greatly encouraged and inspired by Sun Zhongshan, who gave Qiu Jin directions, Tao Chengzhang who was her 
comrade and ally, and Chen Tianhua, who strongly shook Qiu Jin by throwing himself recklessly into the ocean to wake up Chinese people to stand up and fight.

While for Mary Wollstonecraft, she got the publisher Joseph Johnson's appreciation, who was actually the first one to encourage Mary to write what she thought; Thomas Paine, one of the most distinguished British radicals, appreciated Mary's talent and always had heated debates and discussions with her; Henry Fuseli, the Swiss artist; even her rival, Edmund Burke, who wrote Reflections on the French Revolution (1909), stimulated her to write her classic $A$ Vindication of the Rights of Woman.

In brief, the birth of Qiu Jin and Mary Wollstonecraft's feminism ideas came from their own experience, but also under the catalyst of their peers and instructors.

\section{Conclusion}

A shooting star flashes through the sky, leaving sparks and flames for human to see. Qiu Jin and Mary Wollstonecraft just look like two guiding stars, who were brave enough to be themselves and confident to create their own world.

If Qiu Jin's feminism ideas are tough and violent, then, Mary Wollstonecraft's feminism ideas are relatively gentle and mild.

Qiu Jin was one of these bright intellectuals. She always dressed like a man which symbolized that she longed to be a man who could rescue country without any doubt. Her distinctive and radical feminism ideas derived from a strong sense of patriotism. She realized that only the complete social liberation movement can bring truly and meaningful liberation for women.

Mary Wollstonecraft brought out an improved way for the two sexes to live in harmony. That is first to offer women equal education and then pour rationality ideas into women's education. Third, the country should not ignore the significance of a mother's education.

The two heroines both strengthened the importance of education for females. Education is the first and necessary door to open another world for women. They established magazines and newspaper and wrote articles to show their rebellion against man's discrimination. They disagreed to be taken as men's attachment or slave. They called out loudly for equal rights in education, working, and marriage.

Qiu Jin and Mary Wollstonecraft are among the earliest female pioneers in the feminism movement. Their awakening of the subjective consciousness led them to conflicts about dream and reality. Facing this confusing and dark situation, the two pioneers did not surrender but chose to carry on and explore the roads of liberation.

\section{References}

GUO, X. C. (2005). 秋瑾作品中的女权主义思想探析 (An analysis on Qiu Jin’s feminism ideas from her works). 十堰职业技 术学院学报, 18(4), 39-42.

GUO, Y. L. (2011). 秋瑾婚姻的不行与抗争 (The unhappiness and fight over marriage of Qiu Jin). 文史博览 (理论) , (8), 4-7.

LI, X. Z. (2007). 秋瑾女性革命家形象的历史建构 (The construction of Qiu Jin's female revolutionist image). 社会科学研究, (5), 147-152.

LIU, J. (2008). A study on Mary Wollstonecraft's moral thoughts (Master's thesis). Central South University, Hunan Province, China.

Montero, R. (2005). The female biographies (J. WANG, Trans.). Hainan: South Ocean Press. 
SHEN, J. L. (1988). 论秋瑾民主革命思想渐进的三个阶段 (Talks about the three periods of Qiu Jin’s democratic ideas' come into being). 绍兴师专学报, (2), 22-26.

Wollstonecraft, M. (2006). A vindication of the rights of woman (Y. WANG, Trans.). Beijing: Central Edition and Translation Publishing House.

YU, X. Y. (2007). Discussion on the formation of Qiu Jin's democratic thought (Master's thesis). Hunan Normal University, Hunan Pronvince, China.

ZHAO, Y. B. (2007). 沃尔斯通克拉夫特的性别差异与男女平等思想 (Mary Wollstonecraft's gender difference and equality ideas). 绵阳师范学院学报, (6), 105-110.

ZHOU, Y. S. (2009). 秋瑾和晚晴文学新女性形象的塑造 (Qiu Jin and new-woman images in late Qing Dynasty literature). 文 学研究, (11), 111-115. 